\title{
The Role of Knowledge Management on Competitive Advantage in Jordan Manufacturing Companies from Employees Perspectives
}

\author{
Salameh Al- Nawafah ${ }^{1} \&$ Mohammad Nigresh ${ }^{2} \&$ Ali. K. Tawalbeh ${ }^{3}$ \\ ${ }^{1}$ Associate Professor, Princess Alia University College, Jordan \\ ${ }^{2}$ Assistant Professor, Princess Alia University College, Jordan \\ ${ }^{3}$ Dr., AL - Balqa Applied University, Jordan \\ Correspondence: Dr. Salameh Al- Nawafah, Associate Professor, Princess Alia University College, Jordan.
}

Received: April 8, 2019

doi:10.5539/ibr.v12n6p58
Accepted: May 5, 2019

Online Published: May 16, 2019

URL: https://doi.org/10.5539/ibr.v12n6p58

\begin{abstract}
The study aimed to investigate the role of knowledge management on competitive advantage in Jordan manufacturing companies from employee's perspective. The research used the descriptive analytical methodology. In addition a self administrated questionnaire was developed according to research hypothesis and objectives for the purpose of achieve the study objectives. The research sample consisted of. 255 subjects. The self administrated questionnaires were distributed over 0 research sample, 240 questionnaire were collected, therefore the research sample is 240 .. All gathered data were checked and coded then analyzed by using the social Packaging statistical System (SPSS). The study concluded that there is a relationship between knowledge management and competitive advantage in Jordanian industrial companies from the point of view of administrative employee perspectives. In addition the data also concluded that here is a relationship between knowledge generation and competitive advantage. Also there is a relationship between knowledge storage and competitive advantage and there is a relationship between knowledge sharing and competitive advantage in Jordanian industrial companies. The study revealed hat there is a relationship between knowledge application and competitive advantage.... The study recommended that Jordan manufacturing companies have to encourage knowledge management use and to notify their employees with the motives behind such use for obtaining their support.
\end{abstract}

Keywords: knowledge management, competitive advantage, industrial companies

\section{Introduction}

Modern technological changes imposed on organizations regardless of their activities many challenges that had to be faced with modern management methods to enable organization to maintain its survival and increase its ability to achieve its objectives efficiently and effectively. Knowledge management and its programs were the methods proposed by specialists and management scientists to meet these challenges. In order to meet these challenges and improve performance, the application of knowledge management is one of the ways in which organizations can resort to it. This is done through the re-educating and re-training of the labor force in knowledge management, building the knowledge base of the organizations, as well as through the organizations' tendency to collect and disseminate knowledge at all levels of management and develop their quest to invest in acquiring new knowledge and employing the knowledge that it possesses Enabling efficiency and efficiency to the stage of excellence by promoting the so-called best practice.

\section{Problem Statement}

As a result of the role played by knowledge management in most business organizations, knowledge management has become a source of competitive advantage. This means shifting attention from tangible to intangible assets, of which knowledge is the most important. It is worth mentioning that the industrial companies are the most needed to apply knowledge management. Industrial companies are able to control the useful knowledge and able to implement are the most who can gain the competitive advantage. Therefore the study problem is an attempt to investigate the impact of knowledge management on competitive advantage by answering the following questions:

1- Do Jordanian industrial companies apply knowledge management? 
2- What is the role of knowledge management on competitive advantage of Jordanian industrial companies?

3- Do knowledge management elements (knowledge generation, knowledge storage, knowledge sharing and application of knowledge) have a role in competitive advantage?

\section{Study Objectives and Importance}

This study aims to identify the impact of knowledge management on competitive advantage in Jordanian industrial companies in addition to the following:

1. To find out to what extent industrial companies are implementing knowledge management

2. To identify the role of knowledge management elements in competitive advantage of industrial companies

This study importance stems from the importance with the subject it deals with, in addition it may contributes indicating the benefits and advantages of knowledge management implementation for those concerned.

\section{Research Hypotheses}

According and based on previous studies, the research suggests the following hypotheses:

H01: There is no statistically significant role of Knowledge management on Competitive Advantage achievement at the level $\alpha<=0.05$.in Jordanian industrial companies from employees perspective

The following sub hypotheses are derived

- H01.1 There is no statistically significant role of Knowledge generation on Competitive Advantage achievement at the level $\alpha<=0.05$.in Jordanian industrial companies from, employees perspective

- H01.2: There is no statistically significant role of Knowledge storage on Competitive Advantage achievement at the level $\alpha<=0.05$.in Jordanian industrial companies from employees perspective

- H01.3: There is no statistically significant role of Knowledge sharing on Competitive Advantage achievement at the level $\alpha<=0.05$.in Jordanian industrial companies from employees perspective.

- H01.4: There is no statistically significant role of Knowledge application on Competitive Advantage achievement at the level $\alpha<=0.05$.in Jordanian industrial companies from employees perspective

\section{Population and Sampling}

The study population consisted of all employees of industrial companies, listed in Amman Exchange Market. Random sample amounting 240) employees were selected as research sample.

\section{Research Instrument}

The researcher designed a questionnaire to investigate the role of knowledge management in the competitive advantage in industrial companies through using previous studies. The instrument consisted of two parts: the first includes demographic data, while the second part includes statements that measure elements of knowledge management

\section{Instrument Validity}

The questionnaire was proof-read by a panel of university instructors. Their comments and amendments were taken in consideration. Therefore some items were eliminated or added to form the final form of the questionnaire.

\section{Reliability}

Cranach alpha was used to test the consistency. According to this test, the overall reliability level was equal to (0.91) which is considered as an acceptable level of reliability (

Table 1shows values of Cranach's alpha for each variable of the questionnaire and the entire questionnaire.

Table 2 indicate that the total Cranachq'1q1 alpha score was, this means the data obtained is suitable for measuring variables and are subject to high reliability.

Table 1. Instrument Reliability

\begin{tabular}{ccc}
\hline Variables & Cranach Alpha \\
\hline Knowledge Management & Knowledge generation & $74.3 \%$ \\
& Knowledge storage & $72.1 \%$ \\
& Knowledge sharing & $76.2 \%$ \\
Competitive Advantage & Knowledge application & $77.1 \%$ \\
The whole instrument & & $91 \%$ \\
\hline
\end{tabular}




\section{Data Collection Methods}

Two data collection methods are available as follows

\section{Secondary Data:}

The research used published Arabic and foreign books, references, research papers, theses and articles either printed or electronic related to diversification and competitive advantage, in addition to the Internet, and different databases to obtain the latest international researches that handled study topic.

\section{Primary Sources:}

Such data was collected through a survey which was designed and developed according to research objectives based on what was presented theoretically in the literature of knowledge management and competitive advantage.

\section{Data Analysis}

The data were analyzed by using Statistical Package of the Social Sciences (SPSS) the following statistical analysis was used

1-.Descriptive statistics were used for the purpose of obtaining frequencies, percents of demographic variables.

2-Central tendency Measures (means and standard deviations) for sample's responses on the questionnaire statements and to find out the relative importance of the independent variables

Furthermore simple regression and multiple regression were used to find the impact of independents variable on the dependent variables

\section{Knowledge Management}

Knowledge is considered important source to learn new things, solve problems, create core competitiveness in addition to establish new positions either for individuals or for organization now and for the future. Knowledge management refers to the organization's strategic efforts to achieve competitive advantage by exploiting the intellectual assets carried by employees and customers and to learn lessons. (Jamous, 2013, p. 58). In this regard Nasimi, et al, (2013) defined Knowledge management as "a process to helps organizations that identify, select, organize and publish important information and skills which are considered as the institutional memory and typically are not organized".

\section{Knowledge Elements Management}

Knowledge management is a system adopted by the organization based on several interrelated elements and elements that are relevant to achieving the goal set. Knowledge management consists of four basic elements that are mentioned as follows: (Bakush, 2014, pp. 40-41)

\section{A. Personnel}

Knowledge and knowledge management staff is the core part of knowledge management strategy. It is not only because the individual stores the knowledge which organization and staff needs, but also contributes to all stages of knowledge management.

\section{B. Technology:}

Technology is one of the most important tools and knowledge management and one of the most important in generating and creating knowledge from people.

\section{Processes:}

The process provides skill and craft, which are considered the most important sources of knowledge

\section{Strategy:}

Means to act against threats or to exploit opportunities based on strengths, weaknesses and strategy as a knowledge management component that examines the operational methods and roles entrusted to the knowledge management officer and aims to develop the organization's knowledge and sustainability strategy.

\section{Importance of knowledge management}

The importance of knowledge can be summarized as follows: [Hamshari, 2013, pp. 110-112

- Investment of intellectual capital, as the value of organizations (and shares) are greatly affected by the value of intellectual capital (capital Intellectuals) 
- Coordinating various activities of Organization for the purpose of achieving its established objectives, thus enhancing organization's commitment to these activities and objectives;

- Strengthening core competencies of organization;

- Improve organizational performance, as knowledge management generates and implements new knowledge, leading to improved and improved organizational performance;

- Providing organization with an opportunity to identify, document and develop its intangible assets, identify the knowledge required and bridge the gap between them;

- Encourage organizations to encourage the creativity of their human resources to create new knowledge, to renew themselves and to cope with unstable environmental changes

- Building a sustainable competitive advantage for organizations, through the unique adoption of innovations of new ideas, goods and services;

- Improved processes in the Organization, by increasing their effectiveness

- Improvement and development of existing products, new value-added products and knowledge-based products, thereby helping to increase the competitiveness of organization;

- Improve level of human capital by encouraging him to learn, develop his work skills, help him solve his problems, increase his ability to adapt to changes and changes in him, prepare him to absorb change and adapt to it, and increase his spirit of cooperation, teamwork and work satisfaction- ; .

- Reducing costs and raising organization's internal assets to generate new revenue;

- Support efforts to benefit from all tangible and intangible assets by providing a framework for strengthening organizational knowledge;

- Maximize the value of knowledge by focusing on content;

- Encouraging targeted organizational change and business reengineering to achieve the organization's objectives and help it to excel and lead in a rapidly changing and volatile environment.

\section{Knowledge Management Operations}

The following are the main knowledge management operations:

\section{1-Knowledge Capture and Generation}

In order to improve competitive advantage, organizations should have processes of acquiring new knowledge. One of the most important ways to achieve this is to create, generate, develop, build and create knowledge internally. If organizations are not able to develop knowledge among them, there is an alternative to acquiring knowledge from outside sources..(Lekena and Bayaga,2014)

\section{2-Knowledge Storage}

This phase is concerned with the structure and storage of knowledge that has been created or acquired in ways that make it more formal and accessible. This can include other processes such as documentation, coding, sequencing, representation and classification, and knowledge updating (Koech , et al , 2015))

\section{3-Knowledge Sharing}

If knowledge is properly organized and stored, efforts are directed towards making knowledge available to all who needs it. Knowledge that remains under the control of one individual is of little importance to organization as a whole. Since one of the objectives of knowledge management is the participation of every employee in the organization to develop a society to share knowledge, (Muhamad\&Rosmaini , 2010)

\section{4-Knowledge Application:}

This phase or process involves knowledge integration into company's products, services and practices. In general, organizations need to exploit, utilize and apply knowledge in their outputs, operations and practices in order to derive value from them (Chaubey and Chanderkanta.2011)..

\section{Competitive advantage}

Sigalas, et al. (2013, p 324) defined competitive advantage as "the capability of a firm to create more economic value than the least efficient competitions". Competitive advantage is also defined as: "All organization characteristics that distinguish it from other companies that lead to satisfy current or potential customers' wishes and reflect their impact on an increase in market share and profitability (Kadhim, 2014: 11.) In this regard Wang 
(2014) mentioned that attaining this competitive advantage helps the company understand all the changes occurring in its market structure, and thereafter, it can select the most effective and beneficial marketing strategy. Kotler\& Armstrong, (2012).indicated that implementing competitive strategy has many aims as follows:

- To establish company's right positioning.

- To maintain loyal customers.

- To obtain new market share.

- (4)To increase sales.

- To establish effective business performance

\section{Characteristics of Competitive Advantage}

According to Dirisu, et al (2013) competitive advantage has many as follows

1 - it should be sustainable to take the lead in the long term and not only in the short term

2. Competitive advantages usage should match with the objectives and outcomes that the organization wishes to achieve in the short and long term.

3- Follow the policy of continuous change, which seeks to develop the company, and improve performance, and maximize profits.

4. It should be able to attract skilled staff, who have skills, exceptional skills, and innovators who are able to devise new plans and policies for

5- .It should take into consideration and adopts innovation in its policy, and seeks to be unique providing services and goods to customers.

6- It should be flexible in design and implementation of plans

Jeevan Jyoti,. Roomi Rani and Sindhu Kotwal (2013) Knowledge Management Practices and Competitive Advantage: The Mediating Role of Innovation Capacity ,

Conference Paper · December 2013

\section{Knowledge management and competitive advantage}

Various studies were carried out regarding the role of knowledge management in competitive advantage for example:Jeevn, et al (2013) study aimed to investigate the impact of knowledge management on competitive advantage through innovation capacity (mediator) of an organization. The study sample consisted of 331 employees selected from the private telecommunication organizations.. The study concluded that all practices of knowledge management are being practiced by telecommunication organizations. And the innovative capacity is mediated fully the relationship between knowledge management and competitive advantage. Moses, et al (2010)r examined the relationship between knowledge management and competitive advantage, in a developing country.. The study concluded that there is a positive correlation between knowledge management and competitive advantage;

Bahram andMeiham( 2013) found that knowledge management has an impact on the surface of the competitive advantage's Knowledge management and competitive advantage.. The results indicate that Knowledge management has made a significant competitive advantage. Josephine, et al .,(2018)examine the Role of Knowledge Management on the Competitive Advantage of Food and Beverage firms in South East Nigeria. The study found that enhanced collaboration had significant effect on employees' empowerment that increased sales growth in the firm

Ratib, et al ( 2011)assured that there's an effect for the knowledge management on achieving competitive advantage at Jordan Telecom Group( Orange) .In this context Abed Al Ghafour(2015) indicated there is a strong relationship between requirements of knowledge management and competitive advantage Mohammad (2010) found that there isa high impact between knowledge management and competitive advantage .Mohammad (2010) found that there isa high impact between knowledge management and competitive advantage Mundra , et al(2010) concluded that exploring new methods for knowledge management has large impact on companies products and services. They added that innovation is necessary to achieve competitive advantage. Goel (2010) argued that knowledge management assets in improving managerial and organizing aspects in addition to financial issues, which in its turn achieve competitive advantage. Moses, et al (2010)study shows that there is a positive correlation between knowledge management and competitive advantage; which relationship is greatly enhanced by the interaction impact of market orientation. When market-based knowledge is appropriately 
responded to, it augments the competitiveness

Based on the research conducted by Zack (2000)(which included 25 organizations it was found that the relation between knowledge management and the strategic advantages of organizations. Implementing knowledge management processes in organizations should lead to benefits. Competitiveness by enabling the organization to formulate better and more appropriate application of its competitive, care-based strategy and attention to the areas of strategic knowledge in which knowledge management becomes a strategic issue and its direct support of the organization's competitive strategy, and focus on the issue of both strategy and knowledge management come together from the fact that they understand the strategic nature of knowledge itself, and that the strategists in the organizations are aware the strategic role of knowledge, and are therefore able to direct the strategic focus of knowledge and then learning Is within their organizational and strategic responsibilities in the organization, and the organizations are aware and convinced of the relationship between the strategy. Competitiveness and knowledge management that are supposed to emphasize the issue of complimentarily and interrelationship among the implementers of knowledge management and necessity collaborate with their strategists to ensure that the competitive advantages of knowledge management processes are achieved

\section{Data Analysis}

Table 1. Frequencies and Percentages of Respondents according to their Demographic Information

\begin{tabular}{cccc}
\hline Variable & Option & Frequency & Percentage\% \\
\hline Gender & Male & 210 & 87.5 \\
& Female & 30 & 12.5 \\
Age & Less than 25 years & 60 & 25.0 \\
& $25-35$ years & 140 & 58.3 \\
Education level & 36 to -45 years & 40 & 16.7 \\
& High School & 144 & 60 \\
Position & BSc. & 96 & 40 \\
& Head department & 20 & 8.3 \\
Experience & Head section & 72 & 30 \\
& Employee & 148 & 61.7 \\
& Less than 5 years & 80 & 33.3 \\
\end{tabular}

Table (1) indicates that, 87.5 percent of the total sample was male's while12.5 percent were females. Sample's age e ranged from less than 25 years to $45+$ years. $25 \%$ were 60 percent of the sample were less than 25 years, 58.3 percent were between $25-35$ years, and 16.7 percent were between 35 to 45 years. As for education level 60 percent have high school and 40 percent have Bsc degree. With respect to subject's position 8.3 percent were head department, 30 percent were head section and $61.7 \%$ were employees. With regard to years of experience 33.3 percent of the sample have (less than5 years ), 41.7 percent have between ( 5-10 years ) and finally25 percent have $10+$ years

Table 2. Means and standard deviations of sample's responses regarding knowledge generation

\begin{tabular}{|c|c|c|c|c|}
\hline N0 & Questions & Mean & Deviation.S & Rank \\
\hline 1 & The company conducts researches and development continuously & 3.07 & 1.039 & 4 \\
\hline 2 & The company conducts technological studies from time to time & 3.58 & 1.030 & 1 \\
\hline 3 & The company organizes brainstorming sessions & 2.77 & 1.155 & 5 \\
\hline 4 & The company attracts researchers and consultants & 3.33 & 1.160 & 3 \\
\hline 5 & $\begin{array}{c}\text { The company has the technological infrastructure for knowledge } \\
\text { generation }\end{array}$ & 1.93 & 1.274 & 6 \\
\hline \multirow[t]{2}{*}{6} & $\begin{array}{l}\text { The company provides financial provision needed to generate } \\
\text { knowledge }\end{array}$ & 3.47 & 1.214 & 2 \\
\hline & General Average & 3.03 & .707 & \\
\hline
\end{tabular}

Table 2 indicates different degrees of sample's agreement..Statement no. (2)" The company conducts technological studies from time to time" ranked the first, while statement no.(5) " The company has the technological infrastructure for knowledge generation " ranked the last. . The general average confirms the application of knowledge generation by industrial companies in Jordan.This indicates that industrial companies seek to generate knowledge because of its importance to companies activities and its impact on achieving a competitive advantage. It is clear that industrial companies recognize the importance of generating knowledge for their activities. 
Table 3. Means and standard deviations of sample's responses regarding Knowledge storing

\begin{tabular}{ccccc}
\hline No. & Question & Mean & S.Deviation & Rank \\
\hline 7 & The company documents new thoughts & 3.60 & 1.196 & 2 \\
8 & The company uses data base to access needed knowledge & 3.60 & 1.092 & 3 \\
9 & The company classifies the available knowledge & 3.47 & 1.096 & 6 \\
10 & The company uses electronic means to store knowledge & 3.92 & .926 & 1 \\
11 & The company stores knowledge that facilitates its use & 3.53 & 1.016 & 5 \\
12 & Technologies available in the company has the ability to & 3.46 & 1.295 & 7 \\
& store large volume of information & & \\
13 & The company has qualified staff to store the information & 3.22 & 1.637 & 8 \\
14 & The company has the ability to deal with data bases & 3.58 & .030 & 4 \\
& General Mean & 3.55 & .892 & \\
\hline
\end{tabular}

Table 3 indicate subject's sample agreement regarding knowledge storing. Statement no. (10) " The company uses electronic means to store knowledge" ranked the first, while statement no. (13) " The company has qualified staff to store the information " ranked the last. The general average confirms company's strategy regarding knowledge storing

In general, it is clear that the industrial companies are keen to provide the techniques and means through which they can store the knowledge to benefit from them. The total average is 3.31. This indicates that the application of knowledge storage in industrial companies is high because these companies rely heavily on information Which they have to sustain in making decisions and putting these information within reach of the employees of the company:

Table 4. Means and standard deviations of sample's responses regarding sharing

\begin{tabular}{|c|c|c|c|c|}
\hline No. & Question & Mean & S.Deviation & Rank \\
\hline 15 & $\begin{array}{l}\text { The company supports periodical meetings for knowledge } \\
\text { sharing }\end{array}$ & 3.27 & 1.260 & 6 \\
\hline 16 & The company enhances staff communications & 3.45 & 1.048 & 3 \\
\hline 17 & The company hosts experts from outside & 3.63 & 1.104 & 1 \\
\hline 18 & The company purchases the needed knowledge & 3.57 & 1.170 & 2 \\
\hline 19 & The company organizes scientific different meetings & 3.27 & 1.460 & 7 \\
\hline 20 & $\begin{array}{l}\text { The company provides staff with the opportunity of } \\
\text { knowledge sharing }\end{array}$ & 3.30 & .889 & 5 \\
\hline \multirow[t]{2}{*}{21} & $\begin{array}{l}\text { The company provides the worker with all equipment } \\
\text { needed for knowledge access }\end{array}$ & 3.37 & 1.193 & 4 \\
\hline & General Average & 3.4071 & .71493 & \\
\hline
\end{tabular}

Table 4 shows subjects agreement regarding knowledge sharing. Statement no. (17) " The company hosts experts from outside" ranked the first, while statement no. (19) " The company organizes scientific different meetings" ranked the last. The general average confirms company's knowledge sharing..

This indicates the extent to which industrial companies understand the importance of knowledge, sharing which is one of the most important elements of knowledge management without sharing knowledge and distributing it to employees.

Table 5. Means and standard deviations of sample's responses regarding knowledge application

\begin{tabular}{rlccc}
\hline No. & Question & Mean & Deviation & Rank \\
\hline 22 & $\begin{array}{l}\text { The company is keen to implement its available } \\
\text { knowledge in its activities } \\
\text { The provides all facilities to implement the available } \\
\text { knowledge } \\
\text { The company motivates employees to implement the }\end{array}$ & 3.72 & 3.43 \\
available knowledge \\
The company implement knowledge to improves work \\
procedures \\
The company trains some employees outside for \\
$\begin{array}{l}\text { implementing the knowledge } \\
\text { General Average }\end{array}$
\end{tabular}

Table 5 indicates subject's agreement regarding knowledge application. Statement no. (26)" The company trains some employees outside for implementing the knowledge" ranked the first, while statement no.(24) " The company motivates employees to implement the available knowledge " ranked the last. The general average confirms knowledge application 
Table 6. Means and standard deviations of sample's responses regarding Competitive advantage

\begin{tabular}{rlccc}
\hline No. & Question & Mean & S.Deviation & Rank \\
\hline 27 & $\begin{array}{l}\text { The company maintains good quality to face competitors } \\
28\end{array}$ & $\begin{array}{l}\text { The company is keen to have products that match } \\
\text { international standards }\end{array}$ & 2.62 & 1.242 \\
29 & $\begin{array}{l}\text { The company seeks all efforts to improve its products. The } \\
\text { company is keen to meet market needs }\end{array}$ & 3.63 & 1.615 \\
30 & $\begin{array}{l}\text { The company is flexible to accept external environmental } \\
\text { changes }\end{array}$ & 3.37 & 1.207 \\
31 & $\begin{array}{l}\text { The company seeks to innovate new ways to modify its } \\
\text { products } \\
\text { General Mean }\end{array}$ & 3.42 & 1.700 \\
\end{tabular}

Table 6 illustrates subjects' agreement regarding employees competitive advantage no.(29)" The company seeks all efforts to improve its products "While statement no.(28) " The company is keen to have products that match international standards "ranked the last.

Hypotheses Testing According and based on previous studies, the research suggests the following hypotheses:

H01: There is no statistically significant impact of Knowledge management on Competitive Advantage achievement at the level $\alpha<=0.05$.in Jordanian industrial companies from employees perspective

Table 7. Regression model summary for main hypothesis

\begin{tabular}{lccccc}
\hline Variables & $\mathbf{R}$ & R Square & Adjusted R Square & F & Sig \\
\hline & $.874^{\mathrm{a}}$ & .764 & .747 & 44.468 & .000 \\
\hline Model validity was tested through multiple regressions. Table $(12)$ shows the obtained results of the first \\
independent variable that were used in the model $\mathrm{f}=44.468$ at $(0.00)$ level. The correlation coefficient was $(\mathrm{R}$ \\
=.847) which indicate a positive relation between independent variable and dependent variable, in additionR $\mathrm{R}^{2}$ was \\
=.764which indicates that $76.4 \%$ of variance in competitive may be interpreted through the variance knowledge \\
management.
\end{tabular}

Table 8. Regression coefficient for the main hypothesis

\begin{tabular}{cccccc}
\hline & \multicolumn{2}{c}{ Un standardized Coefficients } & S.d Coeff. & & S \\
\cline { 2 - 4 } Model & B & Std. Error & Beta & & T \\
\hline (Constant) & .149 & .324 & & .461 & .647 \\
Knowledge generation & .025 & .109 & .020 & .225 & .823 \\
Knowledge storing & .523 & .103 & .536 & 5.093 & .000 \\
Knowledge sharing & -.276 & .106 & -.227 & -2.593 & .012 \\
Knowledge Application & .624 & .131 & .527 & 4.776 & .000 \\
\hline
\end{tabular}

Table 8 showed that the regression coefficient $(\beta=0.025,0.523,0.276,0.624)$ which indicates that the impact of knowledge management is significant since the values $(0.225,5.093,2.593$ and 4.776$)$ at level $(\mathrm{Sig}=0.000)$ save knowledge generation .therefore the null hypothesis is rejected and the alternative one is accepted. This means that there is statistically significant impact at $(\alpha \leq 0.05)$ level of knowledge management on competitive advantage

\section{The first Sub -hypothesis}

The following sub hypotheses are derived

H01.1 There is no statistically significant impact of Knowledge generation on Competitive Advantage achievement at the level $\alpha<=0$.05.in Jordanian industrial companies from, employees perspective

Table 9. First sub Hypothesis

\begin{tabular}{clccccccc}
\hline Variables & R & R Square & F & Sig & B & Beta & T & Sig. \\
\hline Generation & $.598^{\text {a }}$ & .358 & 32.361 & .000 & .736 & & 5.689 & .000 \\
\hline
\end{tabular}

Table 9 indicates that $\mathrm{F}=32.361$ at $(0.00)$ level .The correlation coefficient $\mathrm{R}=.598$ which indicate a positive relation between independent variable and dependent variable, in addition $R^{2}$ was $=.358$ which indicates that $35.8 \%$ of variance incompetitive advantages may be interpreted through the variance in knowledge generation . This means that the model is valid for interpreting the variance in the dependent variable, so there is a possibility to carry out the multiple regression. Table also indicates that the regression coefficient $(\beta=0.0 .736)$ which indicates that the total impact knowledge generation on competitive advantage is significant since the values $(5.689)$ at level $(\mathrm{Sig}=0.000)$.therefore the null hypothesis is rejected and the alternative one is accepted. This means that there is statistically significant impactat $(\alpha \leq 0.05)$ level of knowledge generationon competitive advantage in industrial companies in Jordan. 


\section{The second sub hypothesis :}

H01.2: There is no statistically significant role of Knowledge storage on Competitive Advantage achievement at the level $\alpha<=0.05$.in Jordanian industrial companies from employees perspective

Table 10. Second sub Hypothesis

\begin{tabular}{ccccccccc}
\hline Variables & $\mathbf{R}$ & R Square & F & Sig & B & Beta & T & Sig. \\
\hline Storing & $.806^{\mathrm{a}}$ & .650 & 107.745 & 0.000 & .786 & .806 & 10.380 & .000 \\
\hline
\end{tabular}

Table 10 indicates that $\mathrm{f}=106.645$ at $(0.00)$ level. The correlation coefficient was $(\mathrm{R}=. .806)$ which indicatea positive relation between independent variable and dependent variable, in addition $R^{2}$ was $=.650$ which indicates that $65 \%$ of variance in competitive advantageis due tothe variance inknowledge storage .

Table 10also indicated atthe regression coefficient $(\mathrm{B}=0.786)$ which indicates that the total impact of knowledge storage on employee performances significant since the values $(10.380)$ at level $(\mathrm{Sig}=0.000)$.therefore the null hypothesis is rejected and the alternative one is accepted.

\section{The third sub hypothesis :}

H01.3: There is no statistically significant impact of Knowledge sharing on Competitive Advantageachievement at the level $\alpha<=0.05$.in Jordanian industrial companies from employees perspective.

Table 11. The third sub hypothesis

\begin{tabular}{clrrrrrrr}
\hline Variables & R & R Square & F & Sig & B & Beta & T & Sig. \\
\hline Sharing & $.423^{\mathrm{a}}$ & .181 & 12.820 & 0.000 & .520 & .423 & 3.480 & .000 \\
\hline
\end{tabular}

Table 11 indicated that $\mathrm{lF}=12.820$ at $(0.00)$ level. The correlation coefficient was $(\mathrm{R}=. .423)$ which indicatea positive relation between independent variable and dependent variable, in addition $R^{2}$ was $=.181$ which indicates that $18.1 \%$ of variance in competitive advantagemay be interpreted through the variance in knowledge sharing This means that there is a possibility to carry out the multiple regression

Table 11 showed that the regression coefficient $(B=0.520)$ which indicates that the impact of knowledge sharing on competitive advantage is significant since $t$ value is $(3.480)$ at level $(\mathrm{Sig}=0.000)$.therefore the null hypothesis is rejected and the alternative one is accepted

\section{The fourth sub hypothesis}

H01.4: There is no statistically significant role of Knowledge application on Competitive Advantage achievement at the level $\alpha<=0.05$.in Jordanian

Table 12. The fourth sub hypothesis

\begin{tabular}{clrrrrrrr}
\hline Variables & R & R Square & F & Sig & B & Beta & T & Sig. \\
\hline Application & $.785^{\text {a }}$ & .620 & 93.610 & 0.000 & .932 & .785 & 9.783 & .000 \\
\hline
\end{tabular}

Table (12) shows that $\mathrm{F}=93.610$ at $(0.00)$ level. The correlation coefficient was $(\mathrm{R}=. .785)$ which indicatea positive relation between independent variable and dependent variable, in addition $R^{2}$ was $=.620$ which indicates that $62 . \%$ of variance in competitive advantage may be interpreted by knowledge application. This means that the model is valid for interpreting the variance in the dependent variable, so there is a possibility to carry out the multiple regression.

Table 12 showed that the regression coefficient $(B=0.932)$ which indicates that the impact of knowledge application on competitive advantage is significant since $\mathrm{t}$ value is $(9.783)$ at level $(\mathrm{Sig}=0.000)$.therefore the null hypothesis is rejected and the alternative one is accepted

\section{Conclusions and Recommendations}

In light of data and information analysis, the study concluded that there is a relationship between knowledge management and competitive advantage in the Jordanian industrial companies from the point of view of administrative employee.

The result is consisted with Jeevn, et al (2013). Which concluded that all practices of knowledge management are being practiced by telecommunication organizations. and Moses, et al (2010) which concluded that there is a positive correlation between knowledge management and competitive advantage; and with Bahram andMeiham (2013) which found that Knowledge management has made a significant competitive advantage. Moreover the results is in consists with Ratib, et al (2011) who assured that there's an effect for the knowledge management on achieving competitive advantage at Jordan Telecom Group(Orange). In this context Abed Al Ghafour (2015) indicated there is a strong relationship between requirements of knowledge management and competitive advantage Mohammad (2010) found that there is a high impact between knowledge management and 
competitive advantage. Mohammad (2010) found that there is a high impact between knowledge management and competitive advantage Mundra,et al (2010) concluded that exploring new methods for knowledge management has large impact on companies products and services. They added that innovation is necessary to achieve competitive advantage. Goel (2010) argued that knowledge management assets in improving managerial and organizing aspects in addition to financial issues, which in its turn achieve competitive advantage. Moses, et al (2010) study shows that there is a positive correlation between knowledge management and competitive advantage; which relationship is greatly enhanced by the interaction impact of market orientation. When market-based knowledge is appropriately responded to, it augments the competitiveness

In addition the data also concluded that here is a relationship between knowledge generation and competitive advantage in the Jordanian industrial companies from the point of view of the administrators. This can be explained by the senior management's understanding of the advantages of knowledge and what information can be given to assist the company in its productive activities. Also there is a relationship between knowledge storage and competitive advantage and there is a relationship between knowledge sharing and competitive advantage in Jordanian industrial companies. The study revealed hat there is a relationship between knowledge application and competitive advantage...

The study recommended Jordanian industrial companies have to encourage the use of knowledge management to achieve the objectives of this use, which is to provide accurate information to decision makers in these companies. It is also recommended to identify the motives of using knowledge management and clarifying them to employees in order to gain their cooperation and motivate them to innovate, which is positively reflected on the performance of the company.

\section{References}

Abed Al, G. S. (2015). Requirements knowledge management among the Palestinian universities to create a cometitive advantage in Gaza Strip MSC, Aqsa Universty .Palestine.

Al-Jamous, A. (2013). Knowledge Management in Business Organizations and its Relation with Modern Theoretical Approaches, Analytical Approach, Approaches, Operations, Strategies, Case Study, Dar Wael Publishing and Distribution, Amman, Jordan.

Bahram, M., \& Hussein, M. (2013). Knowledge Management a way to gain a competitive advantage in firms (evidence of manufacturing companies).

Bakush, R. (2014). The Impact of Knowledge Management on Institutional Performance Excellence, A Case Study of Mami Farm, Commercial and Management Sciences, Al-Arabi Bin Mehdi University, Umm Al-Boaqi.

Chaubey, D. S., \& Chanderkanta, S. (2011). Knowledge Management and its Application In Library Sciences. International Journal of Research in Economics and Social Sciences IJRESS, 1(1).

Dirisu, J. I., Iyiola, O., \& Ibidunni, O. S. (2013). Product Differentiation: A Tool of Competitive Advantage and Optimal Organizational Performance (A Study of Unilever Nigeria PLC). European Scientific Journal (ESJ), 9(34), 258-281.

Firms in South East Nigeria, Business and Management. J. Econ. Bus. Manag, 5(7), 612-622,

Goel, A. K. (2010). Knowledge Management as a Process to Develop Sustainable Competitive Advantage. South Asian Journal of Management, 17(3), 104-111.

Hamshari, O. A. (2013). Knowledge Management - The Road to Excellence and Entrepreneurship, Dar Safa Publishing \& Distribution.

Josephine, I., Orga, C. S. N., \& Emeh, N. C. (2018) The Role of Knowledge Management on the Competitive Advantage of Food and Beverage. International Letters of Social and Humanistic Sciences, 14, 80-91

Kadhem, H. (2014). Using client profitability analysis as strategic tool in customer relationship management and achieving competitive advantage empirical study in Soft Drinks Planr in Babel. Alghari Journal, l7(30).

Koech, S. C., Boit, J. M., \& Maru, L. (2015). Knowledge Storage. Retrieval and Employee Performance: the moderating Role of Employee Engagement. International Journal of Small Business and Entrepreneurship Research, 3(6), 1-13.

Kotler, P., \& Armstrong, G. (2012). Principles of Marketing (14th ed.). New Jersey: Pearson Prentice Hall.

Lekena, L. L., \& A. Bayaga (2014). Knowledge Generation in Educational Research: Case of South Africa. Universities Int J Edu Sci, 7(3), 801-811. https://doi.org/10.1080/09751122.2014.11890244 
Moses, T. K., Joseph, M. N., \& Augustine, A. (2010) Knowledge management and competitive advantage: The interaction effect of market orientation. African Journal of Business Management, 4(14), 2971-2980.

Muhamad, S. C. R., \& Rosmaini, T. (2010). Knowledge Sharing Practice In Organization, international Conference on Ethics and Professionalism.

Mundra and others (2011). "Achieving Competitive Advantage through Knowledge Management and Innovation: Empirical Evidences from the Indian IT Sector". The IUP Journal of Knowledge Management, IX(2).

Nasimi, M. H., Samaneh, N., Masoumeh, A. K., Hadi, S. K. ,Fatemeh, M. B., \& Hadi, M. (2013). Knowledge Management and Competitive Advantage for Orgnizations. Arabian Journal of Business and Management Review, 2(5). https://doi.org/10.12816/0001188

Rafi, A. K. (2014). Sustainable Competitive Advantage through Knowledge Management. International Journal of Advanced Research in Computer Engineering \& Technology (IJARCET) V, 3(4).

Ratib, S., Mohammad, F., Junat, B., \& Ayman, A. H. (201) Knowledge Management Processes and Effect on Achieving Competitive Advantages: A Case Study of Jordan Telecom Group "Orange Jordan. Journal Bussniss Administration, 7(4).

Sigalas, C., Victoria, P. E., \& Nikolaos, B. G. (2013). "Developing a measure of competitive advantage". Journal of Strategy and Management, 6(4), 320-342. https://doi.org/10.1108/JSMA-03-2013-0015

Zack, M. (2000). A strategic pretext for knowledge management norh eastem university USA.

\section{Copyrights}

Copyright for this article is retained by the author(s), with first publication rights granted to the journal.

This is an open-access article distributed under the terms and conditions of the Creative Commons Attribution license (http://creativecommons.org/licenses/by/4.0/). 